\title{
EFFECTIVENESS OF ACCUMULATED HEAT UNITS ON POPULATION FLUCTUATION OF SPINY BOLLWORM AND ASSOCIATED PREDATORS IN COTTON AND MAIZE FIELDS
}

\author{
NADA, M. A., M. G. RAGAB AND A. E.A. AMER \\ Plant Protection Research Institute, ARC, Dokki, Giza
}

(Manuscript received 10 May 2009)

\begin{abstract}
The seasonal fluctuation of the spiny bollworm (SBW), moths, larvae and associated common predators in relation to accumulated heat units, were studied on cotton, Gossypium barbadense, variety Giza 86 and maize, Zea maize (Single cross, 3062), in Gharbia Governorate during two successive seasons, 2007and 2008. Results revealed that the population of male moths occurring five and four peaks for the two cotton seasons, respectively. The larval infestation of SBW on cotton showed up three peaks each successive cotton season. The average number of larvae at the second peak had low average number than the first and third peaks. On the other hand, the larval infestation of SBW on maize occurred in one peak during the appearance of maize flowers male (tassel) and female (silk) and growing ears. The peak of larval infestation on the maize was more than the second peak in the cotton with about five times. Common predators on cotton occurred in three and two peaks during the two seasons, respectively, while on maize, it occurred in two peaks/season. The population of common predators in the maize was lower than in the cotton fields. Regression values between accumulated heat units as independent factor and SBW male moths, larval infestation and common predators in cotton or maize as dependent factors revealed highly significant during the two seasons. The obverse $r^{2}$ values ranged between 0.4883 and 0.9730 . The same trend was found between accumulated SBW male moths and larval infestation in cotton. The obverse $r^{2}$ values ranged between 0.7078 and 0.9182 . Also, the relationships between larval infestations in cotton or maize and associated common predators were highly significant. The obverse $r^{2}$ values ranged between 0.3875 and 0.9864 . General revealed that the accumulated heat units, captured male moths in pheromone traps can be used to predict larval infestation in cotton and maize crops.
\end{abstract}

\section{INTRODUCTION}

The spiny bollworm, (SBW) Earias inuslana (Boisd.), is a serious pest at cotton and other crops in many countries in the world. Its occurrence covers all cultivated areas in Egypt. SBW larvae had been found fed on maize in Egypt (Willcocks, 1925). The infestation of maize ears is quite apparent in the nili crop during September and the first half of October, then it decrease and becomes sparse in December. The beginning of period coincides with the harvesting of cotton. It is likely that the moths 
resulting from larvae reared in cotton bolls become attracted to the silking maize plants. Ears collected during May, June and July from crop grown in March, were free from infestation (Megahed and El- Nahal,1958 \& Nasr and Azab,1969). The population density of SBW is relatively high in autumn, moderate in summer and low in winter and spring (Abdel salam et al., 1994). Ten overlapping generations were recorded by Megahed et al. (1972) under laboratory conditions. While, Abdel salam et al. (1994) recorded 6 peaks for this pest through year under field conditions. Ragab (1999) recorded four distinct peaks during the period from May to November. Planting of corn within cotton field or adjacent to them restored conditions favorable for propagation of natural enemies and, consequently, ultimate in the rate of infestation of cotton plants with pests. Also, intercropping maize or sorghum with cotton plants attracted higher numbers of Spodoptera littoralis (Boisd.) parasites. (Shalaby et al., 1983, Shalaby et al., 1986 \& El-Maghraby, et al., 1993).

The present work was performed to study spiny bollworm population fluctuation on cotton \& maize, associated with predators as affected by accumulated heat units

\section{MATERIALS AND METHODS}

The present study was carried out at Gemmeiza Agric. Res. Station (GARS), ARC, Santa, Gharbia Governorate, Egypt during two successive cotton and maize seasons of 2007 and 2008. The total area planted with cotton and maize at the GARS was about 40\&120 and $40 \& 150$ feddans during 2007 and 2008 seasons, respectively. The experimental area was two feddans per season. The cotton crop occupied in a feddam, also selected the same area for maize vicinity cotton field. The cotton, Gossypium barbadense, variety Giza 86 were planted on the fourth week of March and maize, Zea maize planted at the first week of June during the two successive seasons, respectively. The agronomic practices for the two crops were applied as recommended by Egyptian Ministry of Agricultural and Land Reclamation. No pesticides was used in the experimental area on the two crops, cotton and maize.

Three funnel traps baited with pheromone capsule were fixed in cotton fields throughout a period extended from the first week of May to the $4^{\text {th }}$ week of October during the two cotton and maize seasons 2007and 2008. The pheromone capsules were changed every two weeks. The numbers of SBW male moths caught was recorded weekly. Samples of twenty five and five plants from each cotton and maize experimental area were chosen randomly and inspected weekly. Samples were replicated four times. The inspected period was extended from the first week of May to the $4^{\text {th }}$ week of October for cotton. For maize was from the first week of July to the 
first week of October. The plants were inspected carefully by direct count method number of common predators were recordeded.

Daily maximum and minimum temperatures were obtained from Agricultural Research Center. The degree days were calculated according to Seaver et al. 1990 and the lower and upper temperature thresholds were 11.71 and $30^{\circ} \mathrm{C}$ (unpublished data).

\section{Statistical analysis}

Data were statistically analyzed using 'Costat' program a product of Cohort software Inc., Berkeley, California.

Table 1. the agricultural phenomena recorded for cotton and maize crops during the two experimental seasons.

\begin{tabular}{|l|c|c|}
\hline The phenomenon & cotton & maize \\
\hline Sawing date & $3^{\text {rd }}$ week of March & $1^{\text {st }}$ week of June \\
\hline First square & $3^{\text {rd }}$ week of May & - \\
\hline First flower & $3^{\text {rd }}$ week of June & - \\
\hline Silk formation & - & $4^{\text {th }}$ week of July \\
\hline maize mature & - & $3^{\text {rd }}$ week of Sept. \\
\hline Harvest & - & $1^{\text {st }}$ week of Oct. \\
\hline \multicolumn{1}{|c|}{ First pick of cotton } & - & - \\
\hline \multicolumn{1}{|c|}{ Second pick of cotton } & $4^{\text {th }}$ week of Sept & - \\
\hline
\end{tabular}

Table 2. the common predators (insect and true spider) recorded on cotton and maize crops, during the two experimental seasons.

\begin{tabular}{|l|l|l|}
\hline Scientific name & Family & Order \\
\hline Paederus alfierii & Staphylinidae & Coleoptera \\
\hline Coccinella undecimpunctata & Coccinellidae & Coleoptera \\
\hline Cydonia vicina var. nilotica & Coccinellidae & Coleoptera \\
\hline Cydonia vicina var. isis & Coccinellidae & Coleoptera \\
\hline Scymnus interruptus Boeze & Coccinellidae & Coleoptera \\
\hline Scymnus syriacus & Coccinellidae & Coleoptera \\
\hline Chrysoperla carnea & Chrysopidae & Neuroptera \\
\hline Orious spp. & Anthocoridae & Hemiptera \\
\hline True spider & Araneomorphae & Araneae (Spiders) \\
\hline
\end{tabular}




\section{RESULTS AND DISCUSSION}

\section{Seasonal fluctuation of male moths}

The captured male moths of SBW, E. insulana, per trap, fluctuated during the two cotton seasons of 2007 and 2008 showing up five and four peaks, respectively, (Figures 1-3). During 2007 cotton season, the average number of SBW captured male moths was recorded during the period from the first week of May to the third week of October in five peaks. The population increased gradually from the first record to reach the first peak at the $25^{\text {th }}$ of May. The other four peaks occurred at the $13^{\text {th }}$ of July, $17^{\text {th }}$ of August, $14^{\text {th }}$ of September and $21^{\text {st }}$ of October, respectively. During 2008 cotton seasons, the population was detected as the previous season, but, the population occurred in four peaks. The captured male moths were very low during May and after that increased gradually to reach the first peak at the $21^{\text {st }}$ of June. The other three peaks occurred at the $2^{\text {nd }}$ of August, $6^{\text {th }}$ of September and $4^{\text {th }}$ of October, respectively. The average number of the captured male moths for the two seasons of 2007 and 2008 occurred in four peaks at the $21^{\text {st }}$ of June, $2^{\text {nd }}$ of August, $6^{\text {th }}$ of September and $4^{\text {th }}$ of October, respectively.

These results agree with the finding of Ragab (1999) who recorded four distinct peaks of SBW during the period from May to November. Abdel Salam et al. (1994) recorded 6 peaks for this pest through year. While under laboratory conditions, ten overlapping generations were recorded by Megahed et al. (1972).

\section{Larval infestation in cotton and maize fields}

Larval infestation of SBW in cotton fields recorded through the period from the first week of May to the third week of October showing up three peaks during the two successive cotton seasons of 2007 and 2008. During 2007, larval infestation appeared at the third week of May and increased gradually until the first peak at the $8^{\text {th }}$ of June. The other two peaks occurred at the $3^{\text {rd }}$ of August and $19^{\text {th }}$ of October. The population of larvae at the second peak had low average number followed by the first and third peaks. During 2008 cotton seasons, also three peaks occurred the $14^{\text {th }}$ of Jun, $2^{\text {nd }}$ of August and $18^{\text {th }}$ of October. The average of the two successive cotton seasons of 2007 and 2008 take the same trend, the population of larvae occurred in three peaks.

On maize during 2007, the larval infestation of SBW appeared from the third week of July to the fourth week of September. One peak occurred at $23^{\text {rd }}$ of August. During this period maize flowers male (tassel) and female (silk) appeared and growing to ears. During 2008 maize season a peak occurred, at the $23^{\text {rd }}$ of Aug. The average of the two successive maize seasons of 2007 and 2008 take the same trend. The peak 
of larval infestation on the maize was higher than the second peak in cotton with about five times (Figures 1-3).

These results could be discuses with following hypothesis, during the period which before 1960, the maize was planted in two growing seasons in the year, the first early summer (during March) the second nili (during July). The infestation of maize ears is quite apparent in the nili crop of maize during September and the first half of October, then it decrease and becomes sparse in December. The beginning of period coincides with the harvesting of cotton. It is likely that the moths resulting from larvae reared in cotton bolls become attracted to the silking maize plants. Whereas, ears collected during May, June and July from crop grown in March, were free from infestation. During the period which after 1960, the maize was planted in one time in the year through May - June and the cotton crops had been planted at the same periods(March- April) before and after 1960. Thus, the SBW infestation to cotton and maize coincided with the new environment (Megahed and El- Nahal,1958 \&Nasr and Azab,1969). Kostandy (1988) reported that during August and September, SBW move from okra and maize to the vicinity cotton. The population density of SBW is relatively high in autumn, moderate in summer and low in winter and spring (Abdel Salam et al., 1994).

\section{Common predators associated in cotton and maize fields}

In cotton fields, the common insect predators including (Paederus alfierii, $C$. undecimpunctata, C. vicina, S. interruptus, S.syriacus, C. carnea, Orious spp.and True spider) were recorded through the period from the first week of May to the third week of October. The total number of predators showed up three and two peaks during the two successive cotton seasons of 2007 and 2008, respectively. The population of insect predators during 2007 appeared earlier two weeks than SBW larval infestation at the first week of May and increased gradually until the first peak at the $15^{\text {th }}$ of June. The other two peaks occurred at the $20^{\text {th }}$ of Jul and $31^{\text {st }}$ of August. The population of insect predators at the second peak had large average number followed by the first and third peaks. During 2008 cotton seasons, the detected predators occurred two peaks, at the $28^{\text {th }}$ of Jun and $16^{\text {th }}$ of August. The average of the two successive cotton seasons of 2007 and 2008 take the same trend, the population of predators occurred in two peaks.

In maize fields during 2007, the population of common predators appeared from the fourth week of Jun to the $1^{\text {st }}$ week of October occurred two peaks at the $20^{\text {th }}$ of Jul and $17^{\text {th }}$ of August. Maize flowers male (tassel) and female (silk) appeared and growing to ears during this period. During 2008 maize season, the detected predators occurred two peaks, at the $19^{\text {th }}$ of Jul and $23^{\text {rd }}$ of August. The average of the two 
successive maize seasons of 2007and 2008 take the same trend, the population of predators occurred two peaks. The population of insect predators on the maize was lower than in the cotton (Figures 1-3).

These results discussed with Shalaby et al. (1983) who reported that planting of corn within cotton field or adjacent to them restored conditions favorable for propagation of natural enemies and, consequently, ultimate in the rate of infestation of cotton plants. Planting maize within or surrounded cotton rows attracted more insect predators. On the other hand, three peaks of common insect predators abundance were observed on cotton fields during mid-June, mid-July and the second half of August (El-Maghraby et al., 1993 and Kostandy, 1995)

\section{Effect of heat units and captured male moths \& larval infestation in cotton} and maize related

The relationship between accumulated heat units $(\mathrm{AcHu})$ as independent factor and SBW captured male moths, larval infestation, common predators in cotton and maize as dependent factors were showed in Tables (3-5) during 2007 and 2008 cotton seasons and average. The probability of regression values between ( $\mathrm{AcHu}$ ) and weekly average number and accumulated of captured male moths in sex pheromone funnel taps revealed that the slope values were highly significant for the two seasons and average. The probability values were $0.0001,0.0000 \& 0.0001,0.0000$ and 0.0000 , 0.0000 during $2007 \& 2008$ cotton seasons and average, respectively. Also, $R^{2}$ values were $0.4926,0.7216 \& 0.488301,0.707721$ and $0.5120,0.7157$ for the two seasons and average, respectively. Relationships between AcHu and weekly average number and accumulated of larval infestation in cotton were highly significant for the same seasons and average. The $R^{2}$ values were $0.5522,0.8455 \& 0.6221,0.8608$ and $0.5975,0.8549$ for the two seasons and average, respectively. Relationship between AcHu and accumulated SBW larvae in maize \& common predators in cotton and maize was highly significant (Tables 3-5).

\section{Relationship between male moths captured and larval infestation in cotton and maize}

The probability regression values between accumulated captured male moths and larval infestation in cotton and accumulated larval infestation in cotton and maize were highly significant during the two seasons and average (Table 3-5). The obverse $r^{2}$ values were $0.8991,0.9147,0.7489 \& 0.8989,0.9140,0.7078$ and $0.9182,0.9162$, 0.7279 for the two seasons and average, respectively. 


\section{Relationship between larval infestation in cotton \& maize and associated common predators}

The probability regression of relationships between weekly larval infestations or accumulated one in cotton and weekly accumulated associated common inset predators were highly significant during the two experimental seasons and average. The obverse $r^{2}$ values were $0.4043,0.7117 \& 0.4879,0.7452$ and $0.4516,0.7307$, respectively. In addition weekly average of larval infestations or accumulated one in maize and weekly average accumulated of associated common inset predators was highly significant.

Gawande et al. (2006) reported that the male moth trap catches of $H$. armigera had significant and positive correlation with its egg population in the field and infestation in green fruiting, whereas it non significant correlation with larval population. Egg numbers were significantly higher on okra than on cotton (Ravi et al., 2005).

Therefore, accumulated heat units, catch of pheromone traps and larval infestation of SBW can be used to forecast SBW infestation and associated predators in cotton and /or maize fields. 
1016 EFFECTIVENESS OF ACCUMULATED HEAT UNITS ON POPULATION FLUCTUATION OF SPINY BOLLWORM AND ASSOCIATED PREDATORS IN COTTON AND MAIZE FIELDS 
1018 EFFECTIVENESS OF ACCUMULATED HEAT UNITS ON POPULATION FLUCTUATION OF SPINY BOLLWORM AND ASSOCIATED PREDATORS IN COTTON AND MAIZE FIELDS 
Table 3. Regression equations between weekly accumulated heat units, average number of SBW moths, larvae infest cotton \& maize plants and associated common insect predators during 2007cotton season

\begin{tabular}{|c|c|c|c|c|c|}
\hline \multirow[b]{2}{*}{ Independent } & \multirow[b]{2}{*}{ dependant } & \multicolumn{4}{|c|}{ Equation parameters } \\
\hline & & $\mathrm{a}$ & b & $R^{\wedge} 2$ & $\begin{array}{l}\text { probability } \\
\text { of regression }\end{array}$ \\
\hline DDU & moths & -149.83 & 0.1719 & 0.4926 & 0.0001 \\
\hline DDU & AcMoths & -1315.57 & 1.3304 & 0.7216 & 0.0000 \\
\hline DDU & Larvae in cotton & -7.04 & 0.0107 & 0.5522 & 0.0000 \\
\hline DDU & AcLarvae in cotton & -63.26 & 0.0897 & 0.8455 & 0.0000 \\
\hline DDU & AcPredtos in cotton & -41.10 & 0.1098 & 0.9701 & 0.0000 \\
\hline DDU & AcLarvae in maize & -63.25 & 0.0666 & 0.8291 & 0.0000 \\
\hline DDU & AcPredtos in maize & -27.95 & 0.0328 & 0.8956 & 0.0000 \\
\hline AcMoths & Larvae in cotton & 3.02 & 0.0087 & 0.8991 & 0.0000 \\
\hline AcMoths & AcLarvae in cotton & 31.74 & 0.0596 & 0.9147 & 0.0000 \\
\hline Larvae in cotton & AcPredtos in cotton & 84.57 & 4.9077 & 0.4034 & 0.0005 \\
\hline AcLarvae in cotton & AcPredtos in cotton & 57.06 & 0.9643 & 0.7117 & 0.0000 \\
\hline Larvae in maize & Predtos in maize & 1.09 & 0.2466 & 0.3875 & 0.0012 \\
\hline AcLarvae in maize & AcPredtos in maize & 4.91 & 0.4550 & 0.9183 & 0.0000 \\
\hline
\end{tabular}


Table 4. Regression equations between weekly accumulated heat units, average number of SBW moths, larvae infest cotton \& maize plants and associated common insect predatorsduring 2008 cotton season

\begin{tabular}{|c|c|c|c|c|c|}
\hline \multirow{2}{*}{ Independent } & \multirow{2}{*}{ dependant } & \multicolumn{4}{|c|}{ Equation parameters } \\
\cline { 3 - 6 } & & a & $\mathrm{b}$ & $\mathrm{R} \wedge 2$ & $\begin{array}{c}\text { probability } \\
\text { of regression }\end{array}$ \\
\hline DDU & moths & -161.52 & 0.1497 & 0.4883 & 0.0001 \\
\hline DDU & AcMoths & -1329.02 & 1.1088 & 0.7077 & 0.0000 \\
\hline DDU & Larvae in cotton & -8.90 & 0.0106 & 0.6221 & 0.0000 \\
\hline DDU & AcLarvae in cotton & -85.57 & 0.0904 & 0.8608 & 0.0000 \\
\hline DDU & AcPredtos in cotton & -52.99 & 0.1085 & 0.9734 & 0.0000 \\
\hline DDU & AcLarvae in maize & -104.48 & 0.0926 & 0.8344 & 0.0000 \\
\hline DDU & AcPredtos in maize & -17.11 & 0.0148 & 0.8132 & 0.0000 \\
\hline AcMoths & Larvae in cotton & 3.72 & 0.0097 & 0.8989 & 0.0000 \\
\hline AcMoths & AcLarvae in cotton & 30.52 & 0.0707 & 0.9140 & 0.0000 \\
\hline Larvae in cotton & AcPredtos in cotton & 86.11 & 5.7155 & 0.4879 & 0.0001 \\
\hline AcLarvae in cotton & AcPredtos in cotton & 67.96 & 0.9740 & 0.7452 & 0.0000 \\
\hline Larvae in maize & Predtos in maize & 0.06 & 0.1565 & 0.8798 & 0.0000 \\
\hline AcLarvae in maize & AcPredtos in maize & -0.52 & 0.1604 & 0.9864 & 0.0000 \\
\hline & & & & & \\
\hline & & & & & \\
\hline & & & & & \\
\hline
\end{tabular}


Table 5. Regression equations between weekly accumulated heat units, average number of SBW moths, larvae infest cotton \& maize plants and associated common insect predatorsduring 2007 and 2008 cotton season

\begin{tabular}{|c|c|c|c|c|c|}
\hline \multirow[b]{2}{*}{ Independent } & \multirow[b]{2}{*}{ dependant } & \multicolumn{4}{|c|}{ Equation parameters } \\
\hline & & a & $b$ & $R^{\wedge} 2$ & $\begin{array}{l}\text { probability } \\
\text { of regression }\end{array}$ \\
\hline DDU & moths & -156.29 & 0.1604 & 0.5120 & 0.0000 \\
\hline DDU & AcMoths & -1328.54 & 1.2152 & 0.7157 & 0.0000 \\
\hline DDU & Larvae in cotton & -8.15 & 0.0107 & 0.5975 & 0.0000 \\
\hline DDU & AcLarvae in cotton & -74.50 & 0.0901 & 0.8549 & 0.0000 \\
\hline DDU & AcPredtos in cotton & -47.15 & 0.1092 & 0.9730 & 0.0000 \\
\hline DDU & AcLarvae in maize & -83.28 & 0.0802 & 0.8333 & 0.0000 \\
\hline DDU & AcPredtos in maize & -22.96 & 0.0234 & 0.8908 & 0.0000 \\
\hline AcMoths & Larvae in cotton & 3.24 & 0.0092 & 0.9182 & 0.0002 \\
\hline AcMoths & AcLarvae in cotton & 31.01 & 0.0649 & 0.9162 & 0.0000 \\
\hline Larvae in cotton & AcPredtos in cotton & 85.33 & 5.3648 & 0.4516 & 0.0002 \\
\hline AcLarvae in cotton & AcPredtos in cotton & 62.41 & 0.9705 & 0.7307 & 0.0000 \\
\hline Larvae in maize & Predtos in maize & 0.47 & 0.2028 & 0.8056 & 0.0000 \\
\hline AcLarvae in maize & AcPredtos in maize & 2.04 & 0.2790 & 0.9770 & 0.0000 \\
\hline
\end{tabular}




\section{REFERENCES}

1. Abdel - Salam, N. M., M. A. Nada, A. M. Hossain and A. M. Rashad. 1994. Abundance of spiny bollworm in relation to thermal heat units and host plants. AlAzhar J. Agric. Res., 19 :225- 233.

2. El-Maghraby, M. M. A., M. A. El-Tantawy, E. A. A. Gomaa and M. A. Nada. 1993. Effect of pesticidal application durin the early and late season on the abundance of certain predators associated with cotton plants. Zagazig J. Agric. Res., 26(2A) : 726-737.

3. Gawand, G. V., B. S. Ghodki, H. U. Khambadkar and V. Farkade. 2006. Correlation studies on pheromone trap catches of Helicoverpa armigera with its field infestation. Journal of Soils and Crops, 16(1):250-253.

4. Kostandy, S. N. 1995. The simultaneous effect of early using of insecticides on cotton pests and its related natural enemies. Ann. Agric. Sci., Ain Shams Univ., 40(2)877-889.

5. Kostandy, S. N. 1988. An environmental appraisal of the modern techniques applied in Egypt for the control of certain cotton pests. Ph. D. Dissertation. Inst. Environ. Stud. \& Res., Ain Shams Univ., Egypt.

6. Megahed, M. M. and A. K. M. El-Nahal. 1958. The spiny bollworm, Earias insulana (Boisd.) infesting maize ears in Egypt (Lepidoptera: Agrotidae - Acontiinae). Bull. Soc. Entom. Egypt XL. 11, P. 71-74.

7. Megahed, M. M., M. F. S. Tawfik and A. A. El-Khateeb. 1972. Method of a rearing culture with studies on annual generations of Earias insulana (Boisd.) in laboratory. Bull. Soc. Entom. Egypt L.V1, P. 347-360.

8. Nasr, E. A. and A. K. Azab. 1969. Behaviour and activity of the pink and the spiny cotton bollworms in Egypt. Bull. Soc. Entom. Egypt L.III, P. 235-243.

9. Ragab, M. G. 1999. Ecological studies on cotton bollworm in Egypt. Ph. D. Thesis, Fac. Agric. Al-Azhar Univ. Egypt.

10. Ravi, K. C., K. S. Mohan, T. M. Manjumth, G. Head, B. V. Patil, D. P. A. Greba, K. Premalatha, J. Peter and N.G.V. Rao. 2005. Relative abundance of Helicoverpa armigera (Hubner) (Lepidoptera: Noctuidae) on different host crops in India and the role of these crops as natural refuge for Bacillus thuringiensis cotton. Envi. Entomol., 34 (1):59-69. 
11. Seaver, D., J. Strand and A. J. Strawn. 1990. DDU degree-day utility users guide version 2.0 Univ. of California Division of agriculture and natural Resources UCIPM Publication 9. University of California Integrated Pest Management Program, University of California, Davis.

12. Shalaby, F. F., E. A. Kares and A. A. Ibrahim. 1983. Effect of intercropping maize in cotton fields on the attractiveness of predaceous insects. Annuls of Agric. Sc. Mshtohor, 20(3) : 109-123.

13. Shalaby, F. F., Amira A. Ibrahim Abdel- Gawaad and E. A. Kares. 1986. Effect of intercropping maize in cotton fields on the population of the cotton leaf-worm parasites, their efficiency and the economic income. Bull. Soc. Ent.. Egypt Econ., Ser, 15, 33-44.

14. Willcocks, F. C. 1925. The insect and related pests of Egypt. (Sultanic Agricultural Society, Technical Section, Cairo). 


\section{تذبذب تعداد دودة اللوز الثوكية على القطن والذرة والمفترسات الثائعة المصاحبة متأثرة بالوحدات الحرارية المتجمعة المبن}

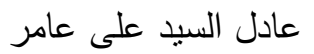

$$
\begin{aligned}
& \text { محمد أحمد محمد ندا محمد جمعه رجب } \\
& \text { معرل بحوث وقاية النباتات - مركز البحوث الزراعبة - دقى - جيزة }
\end{aligned}
$$

تم دراسـة التذبذب الموسمى لتعداد ذكور فراثنـات دودة اللوز الثـوكية ويرقاتها و الففترسـات

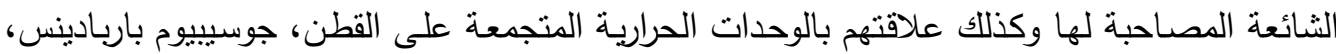

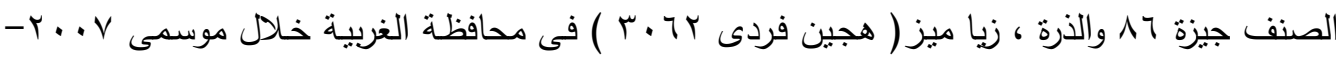

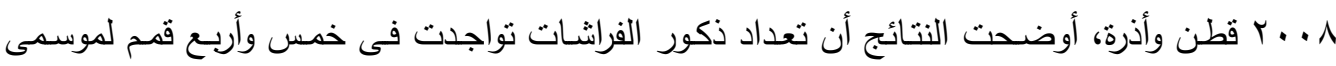

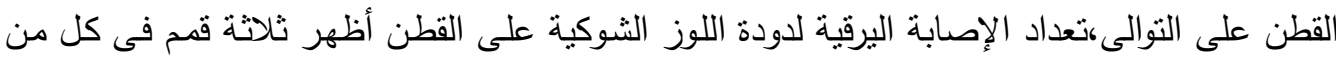

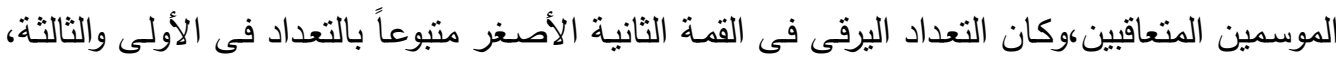

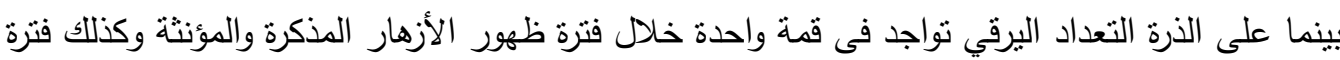

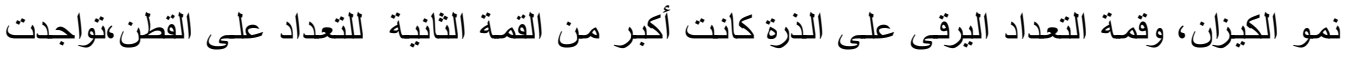

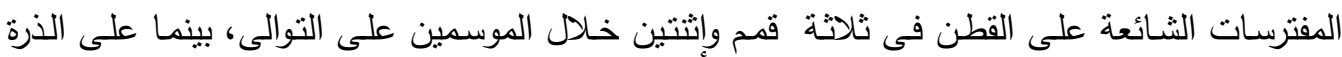

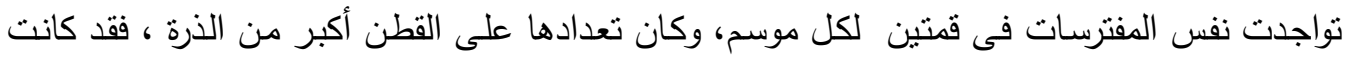

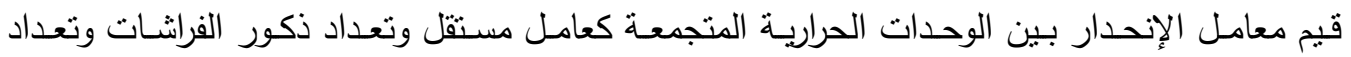

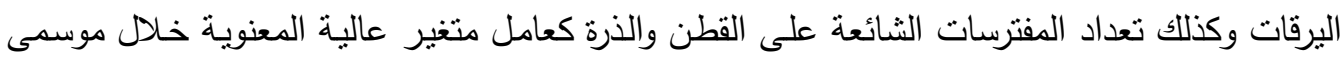

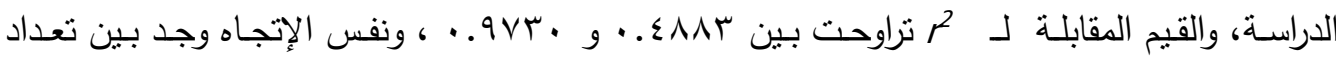

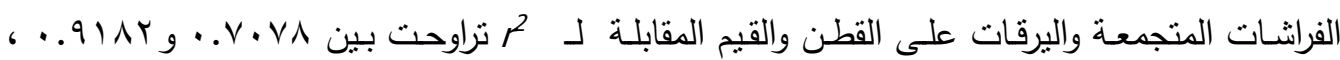

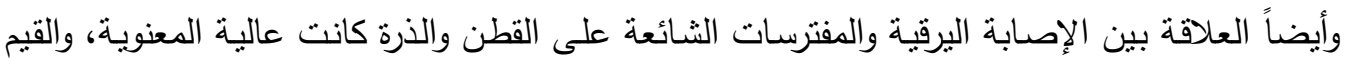

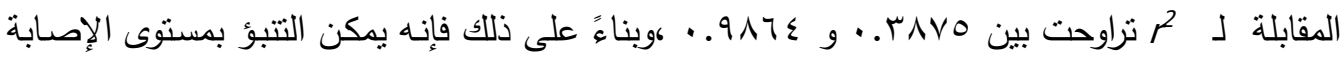
بدودة اللوز الثوكية فى حقول القطن و / أو الذرة باستخدامالوحدات الحرارية المتجمعة وتعداد ذكور

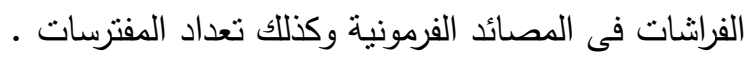

